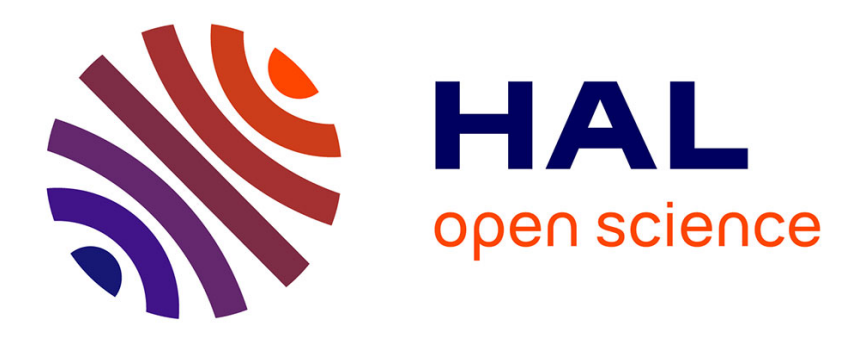

\title{
Yardstick Competition: Which Neighbours Matter?
}

Eric Dubois, Sonia Paty

\section{To cite this version:}

Eric Dubois, Sonia Paty. Yardstick Competition: Which Neighbours Matter?. Annals of Regional Science, 2010, 44 (3), pp.433-452. 10.1007/s00168-008-0273-4 . hal-00800705

\section{HAL Id: hal-00800705 https://hal.science/hal-00800705}

Submitted on 14 Mar 2013

HAL is a multi-disciplinary open access archive for the deposit and dissemination of scientific research documents, whether they are published or not. The documents may come from teaching and research institutions in France or abroad, or from public or private research centers.
L'archive ouverte pluridisciplinaire HAL, est destinée au dépôt et à la diffusion de documents scientifiques de niveau recherche, publiés ou non, émanant des établissements d'enseignement et de recherche français ou étrangers, des laboratoires publics ou privés. 


\title{
Yardstick Competition: Which Neighbours Matter?
}

\author{
Eric Dubois* \\ CNRS-CERAPS (University of Lille 2) \\ eric.dubois-2@univ-lille2.fr \\ and \\ Sonia Paty \\ CNRS-CREM (University of Caen) and EQUIPPE (Universities of Lille) \\ sonia.paty@univ-lille1.fr
}

This version: 2008 September, 24

\begin{abstract}
:
This paper aims at testing the existence of yardstick competition by estimating a fully specified votefunction on a panel data set of 104 French local governments from 1989 to 2001 . When comparing the performance of their incumbent to the one of their "neighbours", voters might consider their close geographical neighbours but also the nearby cities that are similar according to some socio-economic characteristics such as population size. The estimation results show that voters sanction their incumbent if their own local housing tax is high. Moreover, we find that voters reward their incumbent when neighbouring cities that are similar in terms of demographic characteristics have high local taxes.
\end{abstract}

Keywords: yardstick competition, local taxation, municipal elections, vote-function

JEL: H2, H3, H7, D72

*CERAPS, Université de Lille 2, 1 place Déliot, 59024 Lille cedex, France. 


\section{Introduction}

One of the main features emphasized by the economic voting literature is the poor sophistication of voters. Their appraisal of the economic situation is rather rudimentary since they essentially focus on growth rates of macroeconomic variables. From this point of view, some famous American forecasting models are symptomatic (Abramowitz, 2004, Campbell, 2004, Lewis-Beck and Tien, 2004) ${ }^{1}$. Other papers go further in considering more advanced voters.

In Stigler (1973), voters do not take cyclical moves of growth into account but only the permanent component (see also Suzuki and Chappell, 1996). In a somewhat close problematic, Hibbs (1987) shows that the deviation of macroeconomic data from their natural values matters (see also Suzuki, 1994). In Chappell (1983) and in Chappell and Keech (1985b), the voter compares macroeconomic performances obtained by the incumbent with their optimal values. Fiorina (1981) shows that voters can draw "mediated evaluations" by linking economic conditions to the government's policy. In a similar vein, in Chappell and Keech (1985a), the voter is able to identify which economic policy tools are at the disposal of government as well as to see to what extent they are effectively available. According to another type of sophistication, voters are sensitive to macroeconomic variables defined in gap with their expected values. Only non-expected values of macroeconomic variables have an impact on vote. For example, if expected inflation does not influence growth, voters are not likely to punish (respectively, reward) the government when the inflation rate raises (respectively, falls). Here the difficulty lies in choosing the expected values. They can follow from forecasts drawn by a pool of experts (Monroe and Levi, 1983) or from an econometric estimate (Peltzman, 1990, Suzuki, 1991, Palmer and Whitten, 1999, 2002). In Alesina and Rosenthal (1995), voters can distinguish between macroeconomic records obtained by chance and macroeconomic records resulting from government's competence. According to a last characterization of sophistication, voters appraise incumbent's performances at local elections by examining performances obtained by elected people in the neighbourhoods.

There are not many publications aiming at investigating this hypothesis ${ }^{2}$. Besley and Case (1995) mainly explain the probability of incumbent defeat in the US States from 1960 to

\footnotetext{
${ }^{1}$ Of course, the degree of voter's sophistication may vary among these studies, notably regarding the duration on which macroeconomic variables are defined.

${ }^{2}$ Case (1993), whose methods and results are close to Besley and Case (1995), is not considered here.
} 
1988 by two tax variables: "own tax change" (coming with a positive sign) and "neighbours' tax change" (coming with a negative sign). In this respect, voters take the tax change in the nearby states into account when they choose to reward or to sanction their incumbent. This hypothesis, called "yardstick competition", has a strong implication in tax-setting behaviour: since voters are sensitive to neighbours' tax rates, an incumbent should take these taxes into account when setting her own tax rates. This behaviour is thus called "tax mimicking". For example, if all her neighbours lower their tax rates on the election year, it is desirable for the incumbent to lower her own tax rate in her turn in order to be re-elected.

After the pioneer work of Besley and Case (1995), the yardstick competition hypothesis ${ }^{3}$ was rejected in Italy by Bordignon et al. (2002) who used a classical vote-function: the dependent variable is no longer the incumbent's probability of defeat but the incumbent's vote-share. The equation was estimated on a cross-sectional sample of 97 Municipal elections held in Lombardia between 1998 and 2000. Level and change in neighbours' business property tax rates were not significant. In another study, Revelli (2002) aimed at testing a possible yardstick competition effect in 122 English districts on the period 1979-1987. His results confirmed the yardstick competition hypothesis with a negative effect of own property tax increase and a positive effect of neighbours' property tax increase on incumbent voteshare. Vermeir and Heyndels (2006) investigated yardstick voting in Flemish Municipal elections during the period 1982 and 2000. They found that higher rates of local income tax and property tax in neighbouring municipalities were favourable to the incumbents. Finally, Bosch and Solé-Ollé (2007) confirmed that property tax increases in Spanish municipalities, both at the municipal and neighbourhood levels, have the expected impact on the incumbent's share of the vote in three local elections (1995, 1999 and 2003).

Despite their sound econometrics, these studies share a common limit since the votefunction could be better specified ${ }^{4}$. In Besley and Case (1995), tax variables are only controlled by local economic variables ${ }^{5}$ (with the exception of the incumbent's age). Despite the insightful work of Peltzman (1987), national economic variables were not introduced in their analysis. Besides, although it has been shown that they may have an impact on vote

\footnotetext{
${ }^{3}$ Most recent tests of yardstick competition do not rely on estimation of popularity equation, but are based on estimation of tax reaction functions (see the survey of this literature in Revelli, 2005).

${ }^{4}$ Some of these models also exhibit a certain degree of impreciseness. For example, the term of "popularity function" is more suitable when the dependent variable is executive approval (we acknowledge that classical surveys are misleading from this point of view since they usually gather vote and popularity functions under the term "VP-functions" for pedagogic purposes). Another example is the past vote. It is presented as a lagged dependent variable but in fact it is not. Let us take an example. In t-1, Left is incumbent and looses the elections with a vote-share $\mathrm{V}_{\mathrm{t}-1}<50 \%$. So in $\mathrm{t}$, Right is incumbent but the previous vote is not $\mathrm{V}_{\mathrm{t}-1}$ but $\left(100-\mathrm{V}_{\mathrm{t}-1}\right)$.

${ }^{5}$ State income per capita, state's unemployment rate, etc.
} 
(Holbrook, 1991, Campbell, 1992), national and/or political determinants are also virtually absent. Notable efforts were made however by Bordignon et al. (2002) by including several local political variables as the previous vote-share or the incumbency advantage. Bosch and Solé-Ollé (2007) also take into account the influence of underlying political factors such as national political shocks and the ideological bias of the voting population. Although national political shocks are included in the vote-equation, there is no investigation on the effects of national economy's performance on the vote.

Moreover the theoretical foundations of the vote-function are missing. Even if it clearly constitutes the underlying theory of all these models, retrospective voting is not mentioned. The reward / punishment mechanism is not detailed enough and classical references such as Downs (1957b) and Key (1966) are never quoted.

Beside these limits, all the aforementioned studies mainly focus on a single kind of neighbours, namely adjacent geographical neighbours ${ }^{6}$. An interesting extension would be to consider an alternative definition of neighbourhood. For example, when comparing their incumbent's performance, voters may also consider "socio-economic neighbours" which are nearby cities that experience similar cost of public services. For example, the needs in terms of public infrastructure in a large city may be different to the geographical adjacent municipalities' ones. In his paper on the English case, Revelli (2002) notes that the use of alternative weighting schemes, e.g. based on population size, does not produce significantly different results, but leads to an increase in the standard errors of the parameters. Possible effects of economic neighbours have also been investigated in some French studies but only in a tax-setting framework (i.e. through a reaction function that explains tax rates) (Deffains $e t$ al., 1996, Paty, 2006).

In France, several vote-functions at the municipal level already exist (Lafay and Jérôme, 1991, Deffains et al., 1996, Jérôme-Speziari and Jérôme, 2002, Farvaque et al., 2007). Two of them have emphasized taxes as a key determinant of vote. In their cross-sectional sample of 236 cities for the 1995 election, Deffains et al. (1996) found a strong negative significant effect of the level of the business tax two years before on the incumbent vote. In addition, Jérôme-Speziari and Jérôme (2002) show that the evolution of the property tax along the term has a negative effect on the incumbent vote-share. Their sample is composed of 236 cities on

\footnotetext{
${ }^{6}$ In Besley and Case (1995), voters look at neighbours' tax rates that correspond to their income range. Then, there is some kind of economic comparison even though the neighbours are the adjacent states.
} 
two elections, 1989 and 1995. However, none of these two studies have tested a possible yardstick competition effect in Municipal elections ${ }^{7}$.

Consequently, our paper aims at extending the existing literature in three ways. First, yardstick competition in the municipal French case is studied for the first time ${ }^{8}$. Second, different types of neighbourhood based on geographical and socio-economic characteristics are introduced. We aim at determining who are the most relevant neighbours when voters compare the performance of their incumbent. Third, the vote-function is fully specified with both political and economic determinants at both national and local levels.

Our paper is organised as follows: after surveying the main economic voting theories (section 2), we describe the institutional design in both local politics and local tax-setting in France (section 3). Then, we present the empirical model (section 4) and the results (section 5). Finally, section 6 concludes.

\section{Economic voting theories}

If the economy's influence on vote is nowadays largely accepted, the ways in which this influence proceeds remain mysterious ${ }^{9}$.

According to Downs $(1957 a)^{10}$, citizens act rationally in politics as they act rationally in economics: "each citizen views elections strictly as means of selecting the government most beneficial to him. Each citizen estimates the utility income from government action he expects each party would provides him if it were in power in the forthcoming election period" (Downs, 1957a, 138). But collecting and treating the information necessary to appraise the future situation are costly and do not lead the rational voter to gather information. According to the famous oxymoron of Downs (1957a, 139), the voter is "rationally ignorant". Faced with this lack of information, voters can merely do a "referendum on the incumbent management" (Lafay, 1995, 23). This is the classical reward / punishment mechanism first introduced by Key (1966). If the macroeconomic performances obtained by the incumbent are judged as

\footnotetext{
${ }^{7}$ To our knowledge, only one study can be related to ours. In their national vote-function, Jérôme et al. (2001) explain the incumbent vote at French Legislative elections by French macroeconomic variables defined in gap with German values suggesting that French citizens judge their government by comparing their situation to their national neighbours.

${ }^{8}$ Yardstick competition is also studied at the regional level in Feld et al. (2003) but not in a vote-function framework.

$9 \quad$ For a recent survey on economic voting theories, see Lewis-Beck $(2005,2006)$ and Lewis-Beck and Stegmaier (2006).

$10 \quad$ His arguments are extensively developed in Downs (1957b).
} 
satisfactory, she is re-elected and the political status quo is maintained; in the opposite case, they vote against her. This behaviour is labelled as "retrospective voting".

The retrospective theory, tested and empirically verified by Kramer (1971) on aggregate data and by Fiorina (1981) on individual data, was challenged at the beginning of the 80's by an alternative theory, the theory of prospective behaviour, according to which citizens are no longer looking at the past but looking toward the future. If satisfactory economic conditions are expected for the post-electoral period, the incumbent is re-elected even if she has obtained poor economic performances before the elections (Kuklinski and West, 1981).

At the end of the 70's, another cleavage appeared. Until then, following Campbell et al. (1960, 381), voters were considered to vote exclusively according to "their pocketbook", according to the evolution of their personal finances (Weatherford, 1978). Kinder and Kiewiet (1979) first opposed personal grievances to collective judgements. In the first case, voters appraise economic performances from their own point of view and, in the second case, from the point of view of the society as a whole. This last behaviour is qualified of "sociotropic" and is opposed to the "egotropic" one.

\section{French institutional design in local politics and local tax-setting}

\subsection{The setting of Municipal elections}

Municipal elections usually take place every six years in France ${ }^{\mathbf{1 1}}$. All the municipalities vote simultaneously on a Sunday in March. The election consists in electing "municipal councillors". The number of municipal councillors to elect is different from a city to another: from 9 in towns of less than 100 inhabitants to 69 in cities of more than 300.000 inhabitants ${ }^{\mathbf{1 2}}$.

In each municipality, several lists compete ${ }^{\mathbf{1 3}}$. Each list is composed of a number of names equal to the number of seats to fill ${ }^{\mathbf{1 4}}$. There are two rounds separated with 1 week. To be elected at the first round, a list must gather more than $50 \%$ of the votes and the turnout

\footnotetext{
${ }^{11}$ The ballot can be delayed if several different ballots are held in the same year. For example, the Municipal election expected in 2007 will be held in 2008 since Presidential and Legislative elections already take place in this year. In certain circumstances, a by-election is also held (when the mayor passes away or resigns).

${ }^{12}$ Except for Lyon (73 councillors), Marseille (101 councillors) and Paris (163 councillors).

${ }^{13}$ If the city counts less than 3.500 inhabitants, the electoral rules are slightly different. Special dispositions also exist if the population size ranges from 2.500 to 3.499 inhabitants.

${ }^{14}$ The composition of the lists is bound by several rules such as parity between men and women: on each list, the difference between the number of candidates of each gender cannot exceed one. Moreover, each group of six candidates should include an equal number of men and women (in order to prevent women from being systematically placed in an ineligible position).
} 
must exceed $25 \%$ of registered voters. At the second round, only the lists that have gathered $10 \%$ of the votes at the first round can compete. To be elected, a relative majority suffices. Between the two rounds, lists that have obtained between $5 \%$ and $10 \%$ of the votes can combine with one other list. When the results are known, seats are allocated. If only one round has been necessary, the winning list gets half of the total seats. The rest of the seats are shared out between the winning list and the lists that have obtained at least $5 \%$ of the votes according to the proportional rule. The same rule applies if a second round has been necessary. In this case however, the threshold to gain seats is $10 \%$ of the votes.

In the days that follow the elections, the mayor is elected by the municipal councillors. The election of the mayor is therefore indirect (this is why one sometimes speaks about "the third round"). The mayor and the municipal councillors form the "municipal council". To finish, it must be stressed that there is no term limit; an incumbent can be candidate as many times as she wants.

\subsection{The French local taxation system}

In France, the structure of the local public sector is broadly four tiers. The lowest tiers of local governments are made up of 36.600 municipalities and 13.000 groups of municipalities. The middle-tier is made up of 96 departments. Finally, 22 regions are at the highest level of local government. France is usually considered as a unitary country even if the different layers of local governments actually have a large fiscal autonomy. France has the second highest level of tax autonomy of the European Union (54\%) compared with $20 \%$ in Germany which is a federal country or Spain (35\%), the UK being at $14 \%{ }^{15}$.

Local revenue sources mainly come from local taxes (54\%), grants (23\%) and borrowing $(10 \%)$. Each level of local government sets its own tax rate on a common tax base for a large range of local direct taxes, which account for $75 \%$ of local tax revenues. There are two local taxes which are both based on the property's theoretical rental value according to the local land registry. Property tax ("taxe foncière") is payable by the owner while a housing tax ("taxe d'habitation") is payable by the occupier.

Property tax is made up of two parts: a tax rate which applies to the buildings ("taxe foncière sur le bâti") and a tax rate that applies to land belonging to the owners' property ("taxe foncière sur le non bâti"). New buildings and new renovations are exempt from tax for

\footnotetext{
${ }^{15}$ Here, tax autonomy is defined by the proportion of local resources represented by tax revenue over which local authorities have some control (OECD).
} 
two years. The taxes are not applicable to buildings used for agricultural purposes or where the premises are exclusively used for farming, business or student lodgings. People over 75 and those with disability pensions are also exempt and discounts may be available for people over 65 on low incomes.

The local business tax (the so-called "taxe professionnelle") is the remaining and major source of tax revenue for local governments since it accounts for approximately $45 \%$ of revenue from direct local taxes. Its tax base is mainly made up of capital goods and is based on the rental value of buildings as well as on the rental value of equipment.

Although collected centrally, these taxes are distributed to local jurisdictions and are used to finance local public services such as local urban services, building, municipal roads, urban public transport as well as maintaining nursery, primary schools, and sport facilities.

\section{The empirical model}

\subsection{Specification of the vote-function}

The huge amount of empirical articles aiming at testing economic voting theories has not yet brought a clear answer about voters' behaviour. Following the largest part of the existing empirical literature on vote-functions we have retained the retrospective hypothesis. Regarding the social dimension, our model will be composed of egotropic variables as well as sociotropic ones.

The vote-function to be estimated is of the following form:

$$
\mathrm{VOT}=\mathrm{f} \text { (economic factors, political factors) }
$$

The dependent variable, noted VOT, is the vote-share for the coalition of the incumbent candidate at the first round of the 1989, 1995 and 2001 Municipal elections in the 104 French cities with more than 50.000 inhabitants ${ }^{16}$ (see map 1 in appendix). We restricted our analysis to the first round in order to avoid the modelling of complex configurations in the second round ${ }^{17}$. Furthermore, extreme Right (respectively, extreme Left) parties are excluded of the incumbent coalition when the incumbent mayor belongs to the moderate Right (respectively,

\footnotetext{
${ }_{17}^{16}$ According to the 1999 Census.

${ }^{17}$ As we have seen earlier, some lists qualified for the second round may choose to maintain or not and others can combine.
} 
Left) because extreme Right (respectively, extreme Left) vote is seen as a protest vote against the incumbent.

The right side of our equation is composed of twelve potential explanatory variables. First, the variable PREVNAT is the vote-share for the incumbent coalition in the first round of the previous national elections. This variable represents a short-term strength. In our sample, the concerned elections are the 1988 Legislative elections, the 1995 Presidential elections and the 1997 Legislative elections of $1997^{18}$. Expected sign is positive for this variable.

PREVLOC is the vote-share for the incumbent coalition in the first round of the previous Municipal elections. The previous local vote expresses a long-term strength or vote inertia, since many voters vote the same way from one election to the next. This variable may be viewed as a proxy for socio-demographic determinants (religious practice, age, occupation...).

Prime minister's popularity accounts for national economic and political situation. The variable POP is defined as the ratio between people who were satisfied with the PM in the month before the ballot and those who were not. This variable, with regard to its national nature, takes a single value for each election. It has to be multiplied by a dummy that is worth 1 if the municipal incumbent belongs to the political party of the Prime minister, and -1 otherwise. Indeed, we assume that a local incumbent is rewarded (respectively, punished) for good (respectively, poor) macroeconomic records and overall political situation. This is the so-called "national character of local ballots": voters use local elections to send a signal to the government on her (national) politics (see, in the French case, Jérôme and Lewis-Beck, 1999).

The local economic conditions are taken into account by the level of tax rate since local taxation is the only economic variable available every year at the French municipal level. The unemployment rate is available at the municipal level only for the Census years that is in 1990 and in 1999 on the recent period. An unemployment rate by "employment area" is quarterly available since the 90's but employment areas cover a larger territory than municipalities.

Among the three aforementioned local taxes, we focus here on housing tax rate (variable noted TAX) since the housing tax is paid by the larger number of voters. Indeed, property tax is only payable by owners (households and firms) and business tax is only payable by firms.

\footnotetext{
${ }^{18}$ The 1999 European elections have been moved apart because this kind of elections is of little importance in French voters' mind and because the position of each party has more to do with sovereignty than a classical Left/Right opposition. For the Legislative elections, results are not available at a municipal level but at a district level. The difficulty here is that one city may cover several districts. In this case, we have simply summed the vote obtained in each district that is on the municipal territory.
} 
For the latter tax, most municipalities that are grouped in larger jurisdictions called (in French) "Etablissements Publics de Coopération Intercommunale"19 set a single business $\operatorname{tax}^{20}$. In this case, municipalities do not set their own business tax rate anymore, and the single tax rate is the same for all the municipalities belonging to the group.

To define our neighbours' tax variables, we have retained two different schemes of "neighbourhood".

The simplest criterion for selecting "neighbours" is based upon geographical proximity. Since geographical neighbours are likely to experience similar cost shocks, tax rates of municipalities belonging to the same urban area give more comparable information than tax rates in far away municipalities. Moreover, information on nearby municipalities is likely to spread more easily. As a consequence, according to our first level of voters' sophistication, voters compare their own tax rate with the ones of close geographical municipalities. We will then focus on local jurisdictions that belong to the same urban area as each city with more than 50.000 inhabitants. Note that the French definition of urban areas in the typology defined by the French National Statistics Institution (INSEE) from the 1999 Census, is rather broad. It matches rather closely that of metropolitan areas in the US except that the threshold is a much lower one (5.000 jobs instead of 100.000 inhabitants). In our sample, the 104 cities which are large employment centres belong to 65 different urban areas since some cities belong to the same urban areas (see map 2 in appendix). Following the empirical literature, we need to compute for each city of our sample the geographical distance between this city and the other municipalities that belong to the same urban area. We then calculate a weighted average of geographical neighbours' taxes ${ }^{21}$. We build a weight matrix $\mathrm{W}^{\mathrm{d}}$ that imposes a smooth distance decay with weights $\mathrm{w}_{\mathrm{ij}}$ given by $1 / \mathrm{d}_{\mathrm{ij}}$ where $\mathrm{d}_{\mathrm{ij}}$ is the Euclidian distance between jurisdictions $\mathrm{i}$ and $\mathrm{j}$ for $\mathrm{j} \neq \mathrm{i}$. This matrix is row-standardized as it is usually practised in spatial econometrics (Anselin, 1988).

However, it could be argued that comparison is also based on alternative criteria such as demographic or socio-economic characteristics (see Case et al., 1993, for a discussion on the use of these weighting schemes in the estimation of a tax-setting function). In the yardstick competition literature, voters and politicians should also be sensitive to tax-setting policies in jurisdictions that are comparable in terms of socio-economic characteristics since they are

\footnotetext{
${ }^{19}$ Since the 1999 "Chevènement law", these groups of municipalities are particularly favoured in France and have been adopted by a growing set of municipalities (more than 13.000 in 2004).

${ }^{20}$ However, few groups of localities have made an alternative choice that is to set an additional rate of business tax to the one of the municipality.

${ }^{21}$ An alternative way of considering neighbours is based on a simple contiguity matrix, where the value 1 is assigned if two jurisdictions share the same border and zero otherwise. The results (not shown) are very close.
} 
likely to finance similar public services. In this perspective, our second hypothesis embodies an alternative form of voters' sophistication. In their comparison with others cities, we assume that voters may consider the cities that are also comparable from a socio-economic point of view, i.e. that are equivalent in terms of population size. Our second definition of neighbourhood is then a combination of the geographical and the demographic criteria. We define as "demographic and geographical neighbours" the nearby cities where population is higher than 50.000 inhabitants. The tax rates of the 104 cities are weighted by the geographical distance among them. The weighting scheme is given by the weight matrix defined above $\mathrm{e}^{22}$.

NTAX1 and NTAX2 are respectively defined as the tax rates of type 1 and type 2 neighbours, type 1 being the geographical neighbours, type 2 being the demographic and geographical neighbours.

TAX, NTAX1 and NTAX2 are defined in level and not in variation (as in Vermeir and Heyndels, 2006) because preliminary investigations showed that variations were highly correlated with each other. Furthermore, we consider the tax rate of the year prior the elections. Indeed, tax rate for year $\mathrm{n}$ is voted before the election but voters usually do not get this information unless the incumbent or the opposition communicates on this decision. Then, if the election is held in Spring $n$, we include the rate voted in Spring $n-1$ and paid by households in Fall n-1.

Finally, regarding these variables, we will test their possible endogeneity since election results may have some effects on tax rates. We will include simultaneously both type 1 and type 2 neighbours because we want to test which one is the most relevant in explaining incumbent vote-share. Let us note there is no colinearity between NTAX1 and NTAX2 because NTAX1 are the housing tax rates of the neighbouring municipalities that belong to the same urban area of a given city (with more than 50.000 inhabitants) while NTAX2 are the housing tax rates of the other French cities with more than 50,000 inhabitants weighted by their geographical distance to a given city.

Our last block of independent variables aims at catching the context of local elections and in particular the effect of incumbent's individual characteristics. We have defined eight variables, respectively noted INC, MIN, REP, LOCEX, ADV and DUR. All are dummies except DUR. DUR is a duration variable that is defined as the logarithm of the number of

\footnotetext{
${ }^{22}$ We could not use here a simple contiguity scheme because our large cities do not necessarily share a border.
} 
consecutive years spent by the incumbent as a mayor ${ }^{23}$. This variable has an unknown expected sign since it can be viewed as a proxy for experience (positive) but also as a measure of weariness (negative). MIN, REP, LOCEX are worth 1 if the incumbent is also a minister or a former minister of the preceding legislature ${ }^{24}$, a national representative (deputy or senator), a president of a local executive (general council or regional council), and 0 otherwise. $A$ priori, the sign is expected to be positive for these variables since they signal a national competence to voters. The incumbent can be viewed as a network person who can give more credit to a local case or obtain a budget for local projects from the State ${ }^{25}$. But one can also think that the incumbent who multiplies the mandates can be viewed as a person attracted by power. Moreover, voters can think that a national representative will be less present to manage their city. So the signs of all these variables are finally undetermined ${ }^{26}$. INC is worth 1 when the incumbent is competing for re-election and 0 otherwise. Her notoriety ensures her a sort of incumbency advantage independently of her performances. Finally, ADV is an adversity variable that is worth 1 in two cases: (1) the incumbent does not run and a famous candidate from the same party is running, (2) the incumbent is running but a famous candidate from the same party is also running. Voters disappointed by the incumbent can prefer maintaining their vote in the coalition by voting for a famous candidate rather than voting for the opposition or abstaining (see Lewis-Beck, 1986, Anderson, 1995a, 1995b, for the study of the shift of the vote into a coalition of parties). ADV is worth -1 if a famous candidate from the opposition is running and 0 otherwise. Here, a famous candidate is a former minister. The sign for $\mathrm{ADV}$ is expected to be positive. Note that when the incumbent is not running, the value of MIN, REP, PGC, LOCEX is 0. Other contextual variables have been envisaged as for example the number of lists in competition but it does not appear to be relevant since we study the vote in favour of a coalition of parties. It would have been different if we had only taken the vote for the party of the incumbent.

The equation to estimate is then the following:

\footnotetext{
${ }^{23}$ We have taken the logarithm to reduce the variability of the series (the mean of the raw values is 10 years but some incumbents have spent 36 years as a mayor). When the number of years was less than 1, the value of DUR has been set to zero.

${ }^{24} \mathrm{We}$ restricted ourselves to the previous legislature because we think that somebody who served as a minister for a couple of years twenty years ago cannot be considered as an influent person. Voters also know that such a person has very little chance to become a minister again.

${ }^{25}$ A related topic is pork barrelling (see, among others, Alvarez and Saving, 1997).

${ }^{26}$ In his cross-section sample for the 1997 French Legislative elections, Foucault (2006) finds different signs according to the combination of elective offices. Unfortunately, he does not test the Mayor and Deputy or Senator combination since he studies incumbent deputies who seek for re-election and since a deputy cannot simultaneously be a Senator.
} 


$$
\begin{aligned}
& \text { VOT }_{i t}=C+\alpha_{1} \text { PREVNAT }_{i t}+\alpha_{2} \text { PREVLOC }_{i t}+\alpha_{3} \text { POP }_{i t}+\alpha_{4} I N C_{i t}+\alpha_{5} \text { MIN }_{i t}+\alpha_{6} \text { REP }_{i t} \\
& +\alpha_{7} \text { LOCEX }_{i t}+\alpha_{8} \text { DUR }_{i t}+\alpha_{9} A D V_{i t}+\alpha_{10} T X_{i t}+\alpha_{11} N T A X 1_{i t}+\alpha_{12} N T A X 2_{i t}+e_{i t}
\end{aligned}
$$

Our vote-function is fully specified since both political and economic determinants at both national and local levels appear in the right $\operatorname{side}^{27}$.

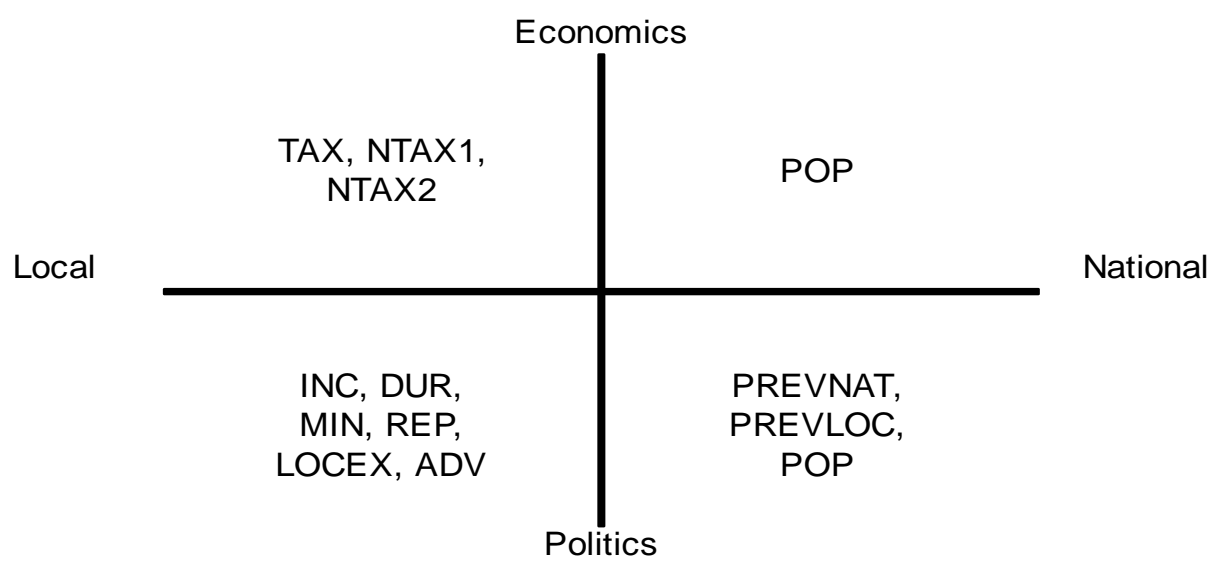

The summary statistics are presented in table $1^{28}$.

Table 1: Summary statistics

\begin{tabular}{lccccc}
\hline \multicolumn{1}{c}{ Variable } & Minimum & Maximum & Mean & Median & Standard Dev. \\
\hline VOT & 29,72 & 83,41 & 53,84 & 54,07 & 10,23 \\
PREVNAT & 29,72 & 91,07 & 55,56 & 55,39 & 9,20 \\
PREVLOC & 15,00 & 78,16 & 45,39 & 44,96 & 8,83 \\
POP & $-1,42$ & 1,42 & 0,02 & 0,00 & 1,24 \\
INC & 0,00 & 1,00 & 0,88 & 1,00 & 0,33 \\
MIN & 0,00 & 1,00 & 0,12 & 0,00 & 0,33 \\
REP & 0,00 & 1,00 & 0,40 & 0,00 & 0,49 \\
LOCEX & 0,00 & 1,00 & 0,02 & 0,00 & 0,15 \\
DUR & 0,00 & 3,58 & 1,91 & 1,79 & 1,08 \\
ADV & $-1,00$ & 1,00 & 0,00 & 0,00 & 0,32 \\
TAX & 3,20 & 29,64 & 15,23 & 15,26 & 4,60 \\
NTAX1 & 5,57 & 17,71 & 10,11 & 10,02 & 1,87 \\
NTAX2 & 9,66 & 19,48 & 14,18 & 14,37 & 2,20 \\
\hline
\end{tabular}

\subsection{Estimation method}

The estimation of our model addresses several econometric issues.

\footnotetext{
${ }^{27}$ This specification is close to the one retained by Auberger and Dubois (2005) for the French Legislative elections. We tried to include a purely national macroeconomic variable such as GDP growth or variation in the national unemployment rate but these variables were too correlated with Prime minister's popularity.

${ }^{28}$ Data sources and correlations between explanatory variables are indicated in appendices (tables 2 and 3 ).
} 
The first econometric problem, which is widely discussed in the literature on politicoeconomic model (see e.g. Frey and Schneider, 1978; Paldam, 1997) is that politicians adapt their tax policy according to their popularity. In that case, the tax variable cannot be assumed to be strictly exogenous. More particularly, there may be shocks to the local government's popularity - included in the error term - that are correlated with the tax increase (Revelli, 2002; Bosch and Solé-Ollé, 2007). Following Revelli (2002) and Bosch and Solé-Ollé (2007), we used an Instrumental Variables (IV) approach to tackle this tax endogeneity problem. We then had to find valid instruments for housing tax rates. They had to be correlated with the municipal housing tax rates but not correlated with the residuals or the share of vote. As in Vermeir and Heyndels (2006), own tax rates were instrumented by the area of the municipality and the number of inhabitants. We also found a third instrument that is the municipal property tax rate. The Sargan test of over-identifying restrictions allowed us to accept the validity of these three variables as instruments.

A second econometric issue arises with the presence of the neighbour's tax variables in the right-hand side of the vote-equation. This may introduce a bias if the error term follows a first-order spatial autocorrelation process:

$$
e_{i t}=\sum_{j=1}^{N} w_{i j} e_{j t}+\varepsilon_{i t}
$$

To solve this problem, instrumental variables is appropriate (see Revelli, 2002, and Bosch and Solé-Ollé, 2007). The same variables as for the own housing tax rates (the area of the municipality, the number of inhabitants and the property tax rates) are valid for both neighbouring tax rates' variables. However, as in Bosch and Solé-Ollé (2007), we performed two tests indicating that it is not necessary to instrument neighbours' tax rates. The Hausman endogeneity test led us to conclude that exogeneity cannot be rejected for both neighbour's tax rates (NTAX1 and NTAX2). Furthermore, we performed a Moran's I test which test for spatial auto-correlation in the error term of our vote-equation using both weight matrices. We could not reject the null hypothesis of an absence of spatial autocorrelation.

Finally, as discussed by Vermeir and Heyndels (2006), the inclusion of fixed effects in our regression may lead to bias if the other variables are not strictly exogenous. There could be an endogeneity problem with the previous vote-share of the current incumbent party. However, it should be noted that PREVLOC is not a lagged dependent variable in the strict 
sense $^{29}$. Therefore our panel is not a dynamic one and estimators such as Arellano-Bond are not necessary.

\section{Results}

The estimation results are presented in tables 4 and 5. Columns 1 to 3 present the estimation results when including respectively both tax rates, the "neighbouring" tax rates NTAX1, the geographical and economic neighbours' tax rates NTAX2. In column 4, we show the estimates when year-dummies are added.

Estimation results using pooled least squares are shown in table 4 in appendix. The Fisher test indicates that the model without fixed-effects is rejected in favour of the fixedeffects model and the Hausman test recommends keeping the fixed-effects model against the random-effects model ${ }^{30}$.

Since the exogeneity tests on each tax rate (TAX, NTAX1 and NTAX2) lead us to conclude that exogeneity is rejected for TAX while not rejected for NTAX1 and NTAX2, we present the estimation results of the IV (2SLS) regression with robust standard errors in table 5. We use the municipal population, the municipal area and the local property tax rates as instruments for tax variables. Hereafter, we only comment the estimation results of the IV (2SLS) regression.

\footnotetext{
${ }^{29}$ This is only a lagged dependent variable when the previous local government remained in power. Consequently, the variable PREVLOC may be problematic only when there is no turnover of power. In our sample, 31 cities out of 104 have changed at least once their political orientation on the period 1989-2001.

${ }^{30}$ The 104 values of the fixed-effects are not shown here for space consideration but are available from the authors upon request. Note also that the White correction have been applied to make the standard errors robust to heteroskedasticity.
} 
Table 5: Estimation results (2SLS)

\begin{tabular}{|c|c|c|c|c|}
\hline \multicolumn{5}{|c|}{ Dependent variable: VOT } \\
\hline & $(1)$ & $(2)$ & $(3)$ & $(4)$ \\
\hline PREVNAT & $\begin{array}{c}0.16^{* * * *} \\
(3.13)\end{array}$ & $\begin{array}{c}0.26 * * * \\
(3.10)\end{array}$ & $\begin{array}{c}0.14 * * * \\
(3.70)\end{array}$ & $\begin{array}{c}0.36^{* * * *} \\
(3.11)\end{array}$ \\
\hline PREVLOC & $\begin{array}{c}0.38 * * * \\
(3.09)\end{array}$ & $\begin{array}{c}0.34 * * * \\
(2.95)\end{array}$ & $\begin{array}{l}0.38 * * \\
(3.20)\end{array}$ & $\begin{array}{l}0.23 * * \\
(2.02)\end{array}$ \\
\hline POP & $\begin{array}{c}0.27 * * * \\
(4.50)\end{array}$ & $\begin{array}{c}0.21 * * * \\
(4.15)\end{array}$ & $\begin{array}{c}0.16^{* * * *} \\
(4.31)\end{array}$ & $\begin{array}{c}0.33 * * * \\
(4.12)\end{array}$ \\
\hline INC & $\begin{array}{l}4.87^{*} \\
(1.80)\end{array}$ & $\begin{array}{c}4.10 \\
(1.57)\end{array}$ & $\begin{array}{l}4.82 * \\
(1.77)\end{array}$ & $\begin{array}{c}3.98 \\
(1.45)\end{array}$ \\
\hline MIN & $\begin{array}{c}1.66 \\
(0.74)\end{array}$ & $\begin{array}{c}1.96 \\
(0.87)\end{array}$ & $\begin{array}{c}1.64 \\
(0.73)\end{array}$ & $\begin{array}{c}1.78 \\
(0.78)\end{array}$ \\
\hline REP & $\begin{array}{l}-0.06 \\
(0.01)\end{array}$ & $\begin{array}{l}-0.05 \\
(0.04)\end{array}$ & $\begin{array}{c}-0.03 \\
(0.02)\end{array}$ & $\begin{array}{l}-0.10 \\
(0.07)\end{array}$ \\
\hline LOCEX & $\begin{array}{l}-4.58 \\
(0.96)\end{array}$ & $\begin{array}{l}-4.86 \\
(1.02)\end{array}$ & $\begin{array}{l}-4.63 \\
(0.98)\end{array}$ & $\begin{array}{l}-3.32 \\
(0.63)\end{array}$ \\
\hline DUR & $\begin{array}{l}-0.05 \\
(0.07)\end{array}$ & $\begin{array}{l}-0.07 \\
(0.10)\end{array}$ & $\begin{array}{l}-0.05 \\
(0.08)\end{array}$ & $\begin{array}{l}-0.03 \\
(0.01)\end{array}$ \\
\hline ADV & $\begin{array}{c}2.80 \\
(1.18)\end{array}$ & $\begin{array}{c}2.62 \\
(1.09)\end{array}$ & $\begin{array}{c}2.72 \\
(1.24)\end{array}$ & $\begin{array}{c}2.44 \\
(1.05)\end{array}$ \\
\hline TAX & $\begin{array}{l}-1.04 * * \\
(2.09)\end{array}$ & $\begin{array}{c}-0.77 * * \\
(2.07)\end{array}$ & $\begin{array}{c}-1.17 * * \\
(2.09)\end{array}$ & $\begin{array}{l}-0.80 * * \\
(2.10)\end{array}$ \\
\hline NTAX1 & $\begin{array}{c}0.53 \\
(0.17)\end{array}$ & $\begin{array}{c}1.14 \\
(0.33)\end{array}$ & - & $\begin{array}{c}0.37 \\
(0.12)\end{array}$ \\
\hline NTAX2 & $\begin{array}{l}1.93 * * * \\
(2.68)\end{array}$ & - & $\begin{array}{l}1.69 * * \\
(2.18)\end{array}$ & $\begin{array}{l}2.41 * * \\
(2.01)\end{array}$ \\
\hline Party*d1989 & - & - & - & $\begin{array}{c}0.08 \\
(0.20)\end{array}$ \\
\hline Party*d1995 & - & - & - & $\begin{array}{l}-0.06 \\
(0.03)\end{array}$ \\
\hline Party*d2001 & - & - & - & $\begin{array}{l}-0.12 \\
(0.04)\end{array}$ \\
\hline $\begin{array}{l}\text { Municipal } \\
\text { effects }\end{array}$ & Yes & Yes & Yes & Yes \\
\hline Adjusted $\mathrm{R}^{2}$ & 0.444 & 0.436 & 0.444 & 0.471 \\
\hline $\begin{array}{l}\text { Number of } \\
\text { observations }\end{array}$ & 312 & 312 & 312 & 312 \\
\hline $\begin{array}{l}\text { Sargan test } \\
\text { Chi-sq. p. value }\end{array}$ & 0.98 & 0.96 & 0.98 & 0.96 \\
\hline
\end{tabular}

Student values are reported in parentheses. *: significant at 10\%; **: significant at 5\%; ***: significant at $1 \%$.

TAX instruments: population, municipal area, property tax

We first comment the column (1). The estimation results show that the effect of own taxes on vote-share for the coalition of the incumbent candidate is negative and significant. We conclude to an electoral impact of housing tax rates. An increase in the tax rate of 1 point 
lowers her vote-share of about 1 point. As expected, incumbents are punished for high housing tax rates. Furthermore, while the coefficient of the neighbouring tax rates (NTAX1) is not significant, the parameter associated with the tax rates of nearby cities that are demographically similar (NTAX2) is significant and positive. This shows that the electoral punishment also depends on tax rates in neighbouring cities that are similar in terms of population size. The effect is strong: when the neighbours raise their tax rates of 1 point, this enhances the incumbent vote-share of about 2 points. Since TAX and NTAX2 exhibit a similar statistical pattern (see table 1), we can even say that the impact of neighbours' taxation on the vote is stronger than the local one. However, tax rates set by neighbouring municipalities of any size (but belonging to the same urban area) do not have any significant impact on municipal vote-share. Then, estimation results confirm that the definition of neighbourhood matters when investigating yardstick competition. In the French case, geographical distance between municipalities is therefore not the only criterion when voters compare the performance of their incumbent with the one of their neighbours. This goes in the sense of Case et al. (1993) who argued that geography might not be the most relevant factor in every context. Citizens are also sensitive to tax-setting policies in jurisdictions that are demographically similar to them because they are more likely to be subject to correlated shocks (Revelli, 2005).

As for the national variables, we get the following results. First, we obtain a positive and strongly significant coefficient for POP (defined as the ratio between people satisfied with the Prime minister in the month before the ballot and people not satisfied). This confirms the hypothesis that a local incumbent is rewarded (respectively, punished) for good (respectively, poor) macroeconomic records and overall political situation. As expected, voters use local elections to send a signal to the government on her (national) politics.

As PREVLOC and PREVNAT are statistically significant with the expected sign, there is strong evidence that the incumbent coalition enjoys both a short-term and a long-term strength by benefiting from the vote-share of parties close to her obtained in the first round of the preceding national elections.

Let us turn to the estimation results of the parameters associated with local political explanatory variables. Since we obtain a positive and significant parameter for the variable INC, results suggest that notoriety ensures the incumbent a sort of incumbency advantage that is independent of her performances. This effect is quite strong: about 5 points. Finally, MIN, REP, LOCEX, DUR, and ADV do not appear significant. Except for ADV, we can think that this non-significance is the result of the presence of two ambivalent effects: one the one hand, 
a positive effect linked to the competence signalled by the possession of another mandate and the notoriety brought by this mandate, on the other hand a negative effect linked to the fear that the future mayor will be less present for the city.

Columns (2) and (3) allow us to check that the outcomes obtained for our tax variables are not subject to a multicolinearity problem: NTAX1 remains not significant when NTAX2 is dropped (column (2)) and NTAX2 remains significant when NTAX1 is dropped (column (3)). Moreover, adding time dummies does not improve the regression (column (4)).

\section{Conclusion}

This paper aimed at testing the existence of yardstick competition by estimating a fully specified vote-function on a panel data set of 104 French local governments from 1989 to 2001.

Estimation results show that voters punish their incumbent if their own local housing tax has increased but reward her if nearby cities that are similar according to their demographic characteristics (i.e. with a population greater than 50.000 inhabitants) have also increased their local taxes. We do not find a similar outcome when defining the neighbours as the municipalities of any size that belong to the same urban area. It means that, for our sample, the relevant neighbours to test the yardstick competition hypothesis are the economic ones not the geographical ones.

These findings are probably due to the specificity of the French local taxation system. The housing tax (which is payable by every occupiers) seems to play a significant role in election choices because it represents a non-negligible expenditure for French inhabitants. Moreover, information on municipal taxation is easily and freely available. On the one hand, information is displayed through the Internet. Numerous blogs draw comparisons between cities taxation. The Administration websites also provide very detailed information on local taxation level. On the other hand, before each ballot, registered voters receive propaganda from the candidates in their letter-box. Statistics about taxation in the city at stake as well as in other cities are regularly found in these advertisements.

While our results provide clear evidence in favour of yardstick competition, they also indicate that together with local taxation, local politics but also national politics and economics have a role in determining Municipal election results. A future agenda of research would lead us to test the yardstick competition hypothesis on local election results at higher 
levels of governments such as departmental and regional level. This would be interesting in order to investigate the behaviour of voters when neighbours are no longer cities but a department or a region since the information on the relevant levels of tax will probably be less precise.

\section{Appendices}

Map 1: French cities with more than 50,000 inhabitants

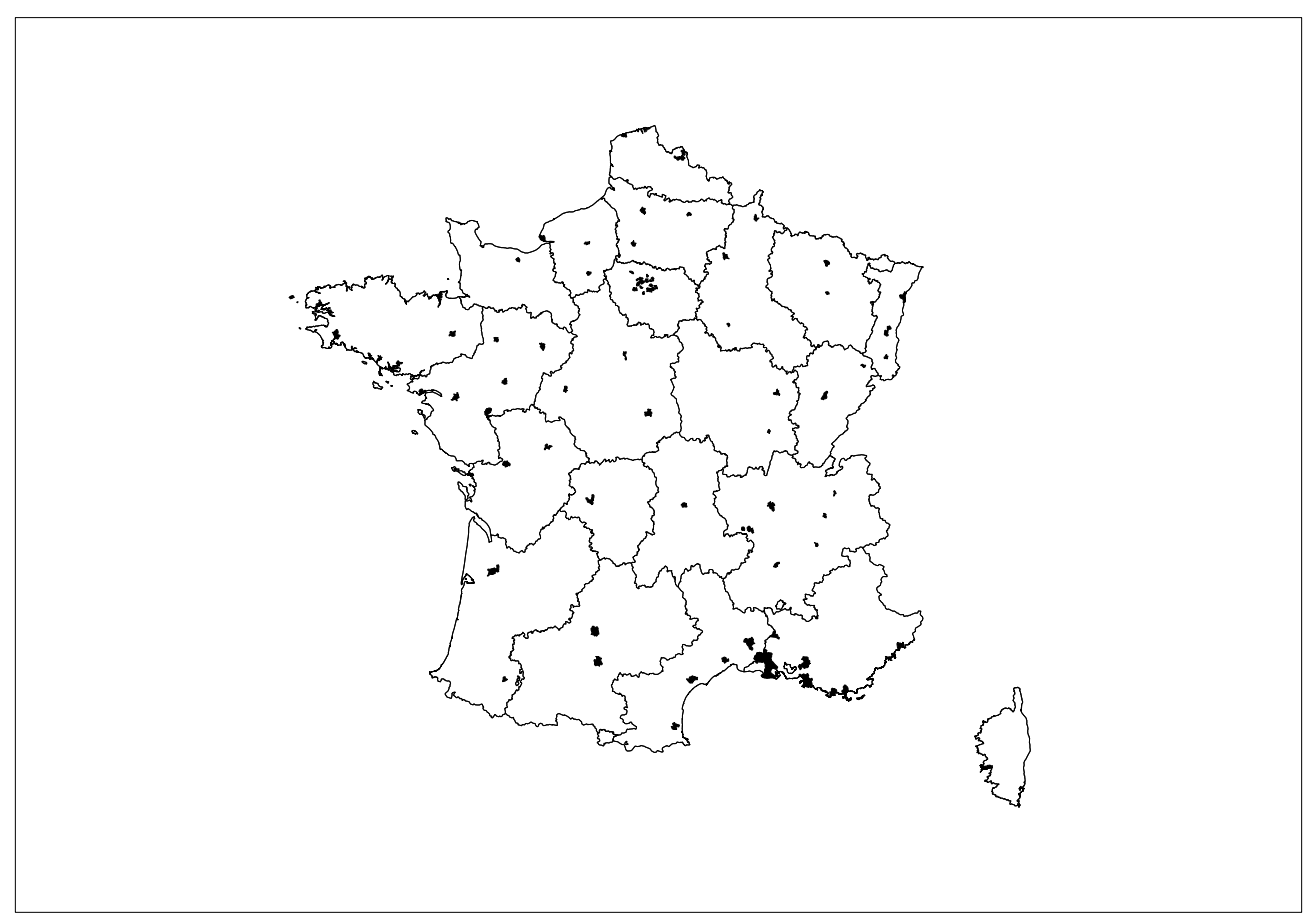

Map 2: The selected urban areas 


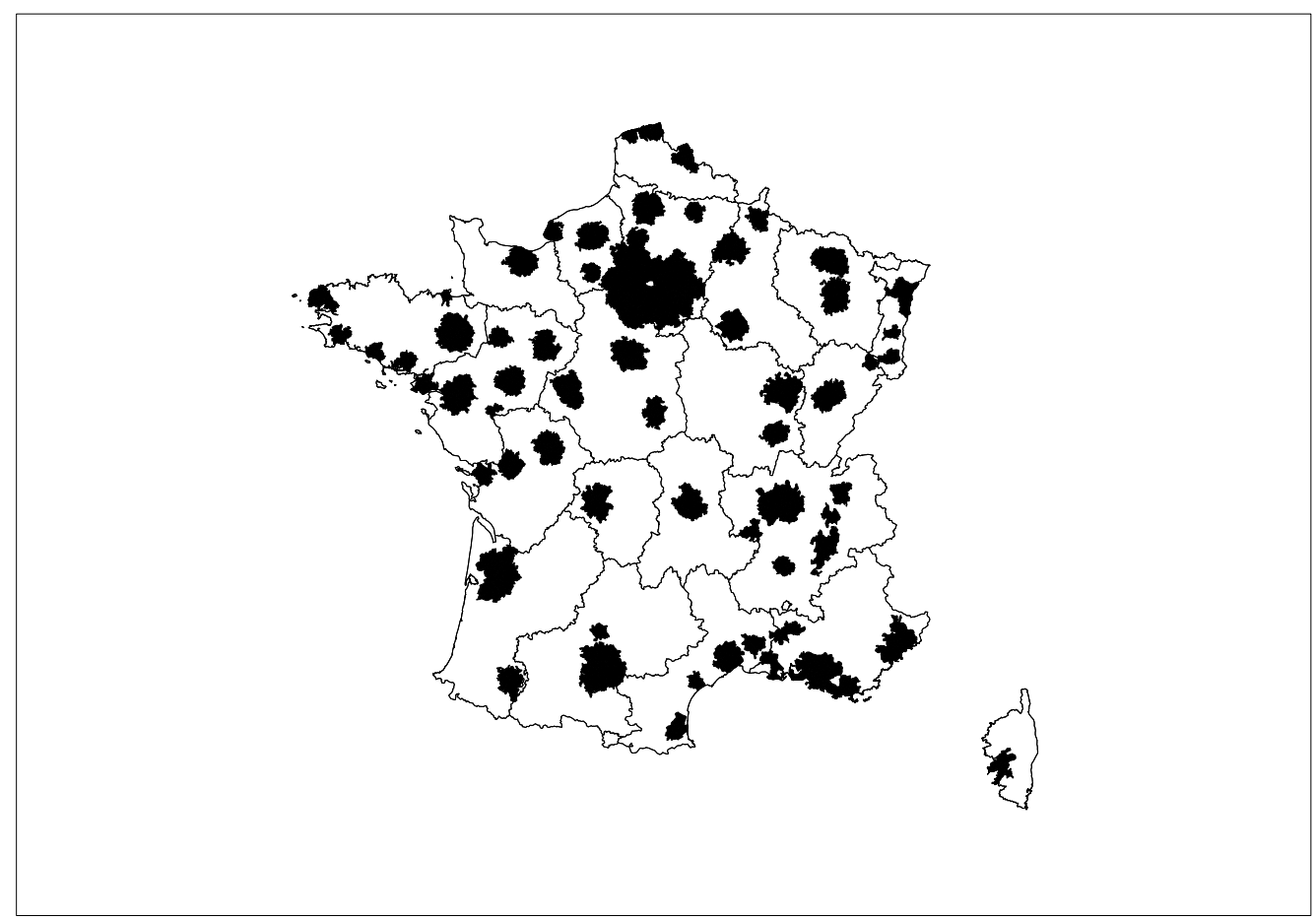

Table 2: Correlations between explanatory variables

\begin{tabular}{|c|c|c|c|c|c|c|c|c|c|c|c|c|}
\hline & PREVNAT & PREVLOC & POP & INC & MIN & REP & LOCEX & DUR & ADV & TAX & NTAX1 & NTAX2 \\
\hline PREVNAT & 1,00 & 0,44 & $-0,22$ & 0,02 & 0,03 & 0,08 & 0,10 & 0,21 & 0,02 & $-0,41$ & $-0,17$ & $-0,27$ \\
\hline PREVLOC & & 1,00 & 0,44 & 0,00 & $-0,01$ & 0,17 & 0,00 & 0,11 & 0,14 & $-0,40$ & $-0,06$ & $-0,37$ \\
\hline POP & & & 1,00 & $-0,14$ & $-0,10$ & 0,00 & $-0,05$ & $-0,07$ & 0,09 & 0,05 & 0,03 & $-0,02$ \\
\hline INC & & & & 1,00 & 0,11 & 0,28 & 0,05 & 0,64 & $-0,28$ & 0,01 & 0,00 & $-0,12$ \\
\hline MIN & & & & & 1,00 & 0,08 & 0,09 & 0,12 & 0,02 & $-0,01$ & $-0,08$ & 0,05 \\
\hline REP & & & & & & 1,00 & 0,00 & 0,26 & $-0,11$ & $-0,05$ & $-0,12$ & $-0,08$ \\
\hline LOCEX & & & & & & & 1,00 & 0,07 & $-0,07$ & $-0,03$ & $-0,15$ & $-0,03$ \\
\hline DUR & & & & & & & & 1,00 & $-0,21$ & $-0,08$ & $-0,08$ & $-0,20$ \\
\hline ADV & & & & & & & & & 1,00 & $-0,11$ & 0,07 & $-0,04$ \\
\hline TAX & & & & & & & & & & 1,00 & 0,39 & 0,72 \\
\hline NTAX1 & & & & & & & & & & & 1,00 & 0,43 \\
\hline NTAX2 & & & & & & & & & & & & 1,00 \\
\hline
\end{tabular}


Table 3: Sources of data

\begin{tabular}{|c|c|}
\hline Variables & Sources \\
\hline VOT & French Home Office* \\
\hline PREVNAT & French Home Office* \\
\hline PREVLOC & French Home Office* \\
\hline POP & polls institute IFOP \\
\hline INC & $\begin{array}{l}\text { constructed from information available on the Internet and } \\
\text { notably on Wikipedia website (fr.wikipedia.org) }\end{array}$ \\
\hline MIN & $\begin{array}{l}\text { constructed from information available on the website of the } \\
\text { French National Assembly (www.assemblee-nationale.fr) } \\
\text { constructed from information available on the website of the }\end{array}$ \\
\hline REP & $\begin{array}{l}\text { French National Assembly (www.assemblee-nationale.fr) and } \\
\text { the French Senate (www.senat.fr) }\end{array}$ \\
\hline LOCEX & $\begin{array}{l}\text { constructed from information available on the Internet and } \\
\text { notably on Wikipedia website (fr.wikipedia.org) }\end{array}$ \\
\hline DUR & $\begin{array}{l}\text { constructed from information available on the Internet and } \\
\text { notably on Wikipedia website (fr.wikipedia.org) }\end{array}$ \\
\hline ADV & $\begin{array}{l}\text { constructed from the nominative electoral results published in } \\
\text { the newspaper Le Figaro and available on the Internet at } \\
\text { elections.figaro.net }\end{array}$ \\
\hline $\mathrm{TAX}$ & Direction Générale des Collectivités Locales (DGCL) \\
\hline NTAX1 & constructed from fiscal information of the DGCL \\
\hline NTAX2 & constructed from fiscal information of the DGCL \\
\hline
\end{tabular}


Table 4: Estimation results (pooled least-squares)

\begin{tabular}{|c|c|c|c|c|}
\hline \multicolumn{5}{|c|}{ Dependent variable: VOT } \\
\hline & $(1)$ & $(2)$ & $(3)$ & $(4)$ \\
\hline PREVNAT & $\begin{array}{l}-0.01 \\
(0.15)\end{array}$ & $\begin{array}{l}-0.02 \\
(0.24) \\
\end{array}$ & $\begin{array}{l}-0.01 \\
(0.14)\end{array}$ & $\begin{array}{l}-0.03 \\
(0.32)\end{array}$ \\
\hline PREVLOC & $\begin{array}{c}0.39 * * * \\
(3.84)\end{array}$ & $\begin{array}{c}0.34 * * * \\
(3.77)\end{array}$ & $\begin{array}{c}0.38 * * * \\
(3.98)\end{array}$ & $\begin{array}{l}0.23^{* *} \\
(2.45)\end{array}$ \\
\hline POP & $\begin{array}{l}-0.00 \\
(0.00) \\
\end{array}$ & $\begin{array}{c}0.02 \\
(0.05) \\
\end{array}$ & $\begin{array}{c}0.00 \\
(0.00) \\
\end{array}$ & $\begin{array}{l}-0.26 \\
(0.45) \\
\end{array}$ \\
\hline INC & $\begin{array}{l}4.97 * * \\
(2.28)\end{array}$ & $\begin{array}{l}4.21 * * \\
(1.98)\end{array}$ & $\begin{array}{l}4.95 * * \\
(2.30)\end{array}$ & $\begin{array}{l}4.21 * \\
(1.92)\end{array}$ \\
\hline MIN & $\begin{array}{c}1.63 \\
(0.89)\end{array}$ & $\begin{array}{c}1.93 \\
(1.05)\end{array}$ & $\begin{array}{c}1.63 \\
(0.89)\end{array}$ & $\begin{array}{c}1.70 \\
(0.92)\end{array}$ \\
\hline REP & $\begin{array}{l}-0.05 \\
(0.04)\end{array}$ & $\begin{array}{l}-0.01 \\
(0.00)\end{array}$ & $\begin{array}{l}-0.05 \\
(0.04)\end{array}$ & $\begin{array}{l}-0.01 \\
(0.01)\end{array}$ \\
\hline LOCEX & $\begin{array}{l}-4.65 \\
(1.22)\end{array}$ & $\begin{array}{l}-4.98 \\
(1.33)\end{array}$ & $\begin{array}{l}-4.66 \\
(1.23)\end{array}$ & $\begin{array}{l}-3.45 \\
(0.83)\end{array}$ \\
\hline DUR & $\begin{array}{l}-0.06 \\
(0.11)\end{array}$ & $\begin{array}{l}-0.09 \\
(0.16)\end{array}$ & $\begin{array}{l}-0.06 \\
(0.11)\end{array}$ & $\begin{array}{l}-0.01 \\
(0.02)\end{array}$ \\
\hline ADV & $\begin{array}{c}2.74 \\
(1.52)\end{array}$ & $\begin{array}{c}2.52 \\
(1.39)\end{array}$ & $\begin{array}{c}2.72 \\
(1.54)\end{array}$ & $\begin{array}{c}2.29 \\
(1.26)\end{array}$ \\
\hline TAX & $\begin{array}{c}-1.32 * * * \\
(2.82)\end{array}$ & $\begin{array}{c}-1.18^{* *} \\
(2.53)\end{array}$ & $\begin{array}{c}-1.34 * * * \\
(3.33)\end{array}$ & $\begin{array}{c}-1.47 * * * \\
(3.26)\end{array}$ \\
\hline NTAX1 & $\begin{array}{l}-0.16 \\
(0.14)\end{array}$ & $\begin{array}{l}1.83 * * \\
(2.15)\end{array}$ & - & $\begin{array}{c}0.57 \\
(0.49) \\
\end{array}$ \\
\hline NTAX2 & $\begin{array}{l}2.01 * * \\
(2.18)\end{array}$ & - & $\begin{array}{c}1.93 * * * \\
(2.85)\end{array}$ & $\begin{array}{c}2.63 * * * \\
(2.79)\end{array}$ \\
\hline Party*d1989 & - & - & - & $\begin{array}{c}7.07 * * * \\
(3.17)\end{array}$ \\
\hline Party*d1995 & - & - & - & $\begin{array}{l}-0.21 \\
(0.11)\end{array}$ \\
\hline Party*d2001 & - & - & - & $\begin{array}{l}-0.33 \\
(0.13)\end{array}$ \\
\hline $\begin{array}{l}\text { Municipal } \\
\text { effects }\end{array}$ & Yes & Yes & Yes & Yes \\
\hline F-test (p-value) & 0.00 & 0.00 & 0.01 & 0.01 \\
\hline $\begin{array}{l}\text { Hausman test } \\
\text { (p-value) }\end{array}$ & 0.00 & 0.00 & 0.00 & 0.00 \\
\hline Adjusted $\mathrm{R}^{2}$ & 0.442 & 0.437 & 0.445 & 0.475 \\
\hline $\begin{array}{l}\text { Number of } \\
\text { observations }\end{array}$ & 312 & 312 & 312 & 312 \\
\hline
\end{tabular}




\section{References}

Abramovitz, A.L. (2004) When Good Forecasts Go Bad: The Time-for-Change Model and the 2004 Presidential Election, PS 37(4), 745-746.

Alesina, A. and H. Rosenthal (1995) Partisan Politics, Divided Government, and the Economy, New York: Cambridge University Press.

Alvarez, R.M. and J. Saving (1997) Deficits, Democrats, and Distributive Benefits: Congressional Elections and the Pork Barrel in the 1980s, Political Research Quarterly 50(4), 809-831.

Anderson, C.J. (1995a) Blaming the Government: Citizens and the Economy in Five European Democracies, London: M.E. Sharpe.

Anderson, C.J. (1995b) The Dynamics of Public Support for Coalition Governments, Comparative Political Studies 28(3), 350-383.

Anselin, L. (1988) Spatial Econometrics: Methods and Models, Kluwer Academic Publishers.

Auberger, A. and E. Dubois (2005) The Influence of Local and National Economic Conditions on French Legislative Elections, Public Choice 125(3-4), 363-383.

Besley, T. and A.C. Case (1995) Incumbent Behavior: Vote Seeking, Tax Setting, and Yardstick Competition, American Economic Review 85(1), 25-45.

Bordignon, M., F. Cerniglia and F. Revelli (2002) In Search for Yardstick Competition: Property Tax Rates and Electoral Behavior in Italian Cities, CESifo Working Paper No. 644 (1).

Bosch, N. and A. Solé-Ollé (2007) Yardstick Competition and the Political Costs of Raising Taxes: An Empirical Analysis of Spanish Municipalities, International Tax and Public Finance 14(1), 71-92.

Campbell, A., P.E. Converse, W.E. Miller and D.E. Stokes (1960) The American Voter, New York: John Wiley \& Sons.

Campbell, J.E. (1992) Forecasting the Presidential Vote in the States, American Journal of Political Science 36(2), 386-407.

Campbell, J.E. (2004) Forecasting the Presidential Vote in 2004: Placing Preference Polls in Context, PS 37(4), 763-767.

Case, A.C. (1993) Interstate Tax Competition after TRA 86, Journal of Policy Analysis and Management 12(1), 136-148.

Case, A.C., H.S. Rosen and J.R. Hines (1993) Budget Spillovers and Fiscal Policy Interdependence: Evidence from the States, Journal of Public Economics 52(3), 285-307.

Chappell, H.W. (1983) Presidential Popularity and Macroeconomic Performance: Are Voters Really So Naïve?, Review of Economics and Statistics 65(3), 385-392.

Chappell, H.W. and W.R. Keech (1985a) The Political Viability of Rule-Based Monetary Policy, Public Choice 46(2), 125-140.

Chappell, H.W. and W.R. Keech (1985b) A New View of Political Accountability for Economic Performance, American Political Science Review 79(1), 10-27. 
Deffains, B., B. Jérôme and V. Speziari (1996) Décentralisation et compétition fiscale : les limites à la dynamique concurrentielle des territoires, in J. Brot (ed), Entreprise, région et développement, mélanges en l'honneur de René Gendarme, Editions Serpenoise, 155-172.

Downs, A. (1957a) An Economic Theory of Political Action in Democracy, Journal of Political Economy 65(2), 135-150.

Downs, A. (1957b) An Economic Theory of Democracy, New York: Harper \& Row.

Dubois, E., M. Leprince and S. Paty (2007) The Effects of Politics on Local Tax Setting: Evidence from France, Urban Studies 44(8), 1603-1618.

Farvaque, E, N. Jean and B. Zuindeau (2007) Inégalités écologiques et comportement électoral : le cas des élections municipales françaises de 2001, Développement durable et territoires. http://developpementdurable.revues.org

Feld, L.P. and J.M. Josselin (2003) Tax Mimicking among Regional Jurisdictions, in A. Marciano and J.M. Josselin (eds), From Economic to Legal Competition. New Perspectives on Law and Institutions in Europe, London: Edward Elgar, 105-119.

Frey, B.S. and F. Schneider (1978) A Politico-economic Model of the United-Kingdom, Economic Journal 88, No 350, 243-253.

Fiorina, M.P. (1981) Retrospective Voting in American National Elections, Yale University Press.

Foucault, M. (2006) How Useful is the Cumul des Mandats for Being Re-elected? Empirical Evidence from the 1997 French Legislative Elections, French Politics 4(3), 292311.

Hibbs, D.A. (1987) The Political Economy of Industrial Democracies, Cambridge, MA: Harvard University Press.

Holbrook, T.M. (1991) Presidential Elections in Space and Time, American Journal of Political Science 35(1), 91-109.

Jérôme, B. and V. Jérôme-Speziari (2002) Les municipales de mars 2001 : vote récompense ou vote sanction ?, Revue française de science politique 52(2-3), 251-273.

Jérôme, B., V. Jérôme-Speziari and M.S. Lewis-Beck (2001) Evaluation économique et vote en France et en Allemagne, in B. Cautrès and D. Reynié (eds), L'opinion européenne, Paris: Presses de Sciences Po, Fondation Robert Schuman, 101-122.

Jérôme, B. and M.S. Lewis-Beck (1999) Is Local Politics Local? French Evidence, European Journal of Political Research 35(2), 181-197.

Key, V.O. (1966) The Responsible Electorate: Rationality in Presidential Voting, Cambridge, MA: Harvard University Press.

Kinder, D.R. and D.R. Kiewiet (1979) Economic Discontent and Political Behavior, the Role of Personal Grievances and Collective Economic Judgements in Congressional Voting, American Journal of Political Science 23(3), 495-527.

Kramer, G.H. (1971) Short-Term Fluctuations in U.S. Voting Behavior, 1896-1964, American Political Science Review 65(1), 131-143.

Kuklinski, J. and D. West (1981) Economic Expectations and Voting Behavior in United States House and Senate Elections, American Political Science Review 75(2), 436-447. 
Lafay, J.-D. (1995) Les interactions entre économie et politique, Journal de la Société de Statistique de Paris 136(1), 17-28.

Lafay, J.-D. and B. Jérôme (1991) Qualité de la gestion municipale et résultats électoraux des maires sortants : analyse empirique des élections de mars 1989, Économie (Université de Perpignan), 35-50.

Lewis-Beck, M.S. (1986) Comparative Economic Voting: Britain, France, Germany, Italy, American Journal of Political Science 30(2), 315-346.

Lewis-Beck, M.S. (2005) Election Forecasting: Principles and Practice, British Journal of Politics and International Relations 7(2), 145-164.

Lewis-Beck, M.S. (2006) Does Economics Still Matter? Econometrics and the Vote, Journal of Politics 68(1), 208-212.

Lewis-Beck, M.S. and M. Stegmaier (2007) Economic Models of Voting, in R.J. Dalton and H.-D. Klingemann (eds), Oxford Handbook of Political Behavior, Oxford: Oxford University Press.

Lewis-Beck, M.S. and C. Tien (2004) Jobs and the Job of President: A Forecast for 2004, PS 37(4), 753-758.

Monroe, K.R. and M.D. Levi (1983) Economic Expectations, Economic Uncertainty, and Presidential Popularity, in K.R. Monroe (ed) The Political Process and Economic Change, New York: Agathon Press, 214-231.

Palmer, H.D. and G.D. Whitten (1999) Voter Rationality and the Effects of Unexpected Inflation and Unexpected Growth: Party Support among European Union Citizens from 19761992, prepared for the workshop "Political Institutions: Intermediaries Between Economics and Politics?", Mannheim, March, 26-31.

Palmer, H.D. and G.D. Whitten (2002) Economics, Politics, and the Cost of Ruling in Advanced Industrial Democracies: How Much Does Context Matter?, in H. Dorussen et M. Taylor (eds) Economic Voting, Routledge / ECPR, 66-91.

Paldam, M. (1997) Political Business Cycles. In D. Mueller (ed), Perspectives on Public Choice: A Handbook. Cambridge: Cambridge University Press, 342-370.

Paty S. (2006) Le rôle des interactions dans les choix fiscaux des agglomérations françaises, Revue française d'économie 20(3), 87-114.

Peltzman, S. (1987) Economic Conditions and Gubernatorial Elections, American Economic Review 77(2), 293-297.

Peltzman, S. (1990) How Efficient is the Voting Market?, Journal of Law and Economics 33(1), 27-63.

Revelli, F. (2002) Local Taxes, National Politics and Spatial Interactions in English District Election Results, European Journal of Political Economy 18(2), 281-299.

Revelli, F. (2005) On Spatial Public Finance Empirics, International Tax and Public Finance 12(4), 475-492.

Stigler, G.J. (1973) General Economic Conditions and National Elections, American Economic Review 63(2), 160-167.

Suzuki, M. (1991) The Rationality of Economic Voting and the Macroeconomic Regime, American Journal of Political Science 35(3), 624-642. 
Suzuki, M. (1994) Evolutionary Voter Sophistication and Political Business Cycle, Public Choice 18(3-4), 241-261.

Suzuki, M. and H.W. Chappell (1996) The Rationality of Economic Voting Revisited, Journal of Politics 58(1), 224-236.

Veirmer, J. and B. Heyndels (2006) Tax Policy and Yardstick Voting in Flemish Municipal Elections, Applied Economics 38(19), 2285-2298.

Weatherford, M.S. (1978) Economic Conditions and Electoral Outcomes: Class Differences in the Political Response to Recession, American Journal of Political Science 22(1), 917-938. 